\title{
AOR
}

Selected Papers of \#AolR2019:

The $20^{\text {th }}$ Annual Conference of the Association of Internet Researchers Brisbane, Australia / 2-5 October 2019

\section{CENTRAL AMERICAN MIGRATION: TRUSTING THE MOBILE PHONE TO CROSS BORDERS}

\author{
Michele Francis Ferris-Dobles \\ University of Illinois at Chicago
}

\section{Extended Abstract}

Mobile phones have become ubiquitous tools for hundreds of thousands of Central American migrants in their transit from their home countries towards the United States (U.S). Carrying a mobile phone and having access to the Internet has become a priority to many migrants during their journey as these tools allow them to communicate with their family and acquaintances who might assist them during their migratory process. Central American migrants invest a significant amount of their limited budget in mobile phones and Internet coverage plans because they feel that access to communication provides them with security. They use social networking sites, like Facebook, and instant messaging applications, like WhatsApp, to contact relatives to transfer money, and to reach people who can provide them with useful information regarding routes and shelters. They also are increasingly using apps like Google Maps to locate themselves while in transit in unknown regions (Barros, 2017). Communication technologies and mobile phones provide for this group of people feelings of safety and closeness.

Migrants trust that in times of crisis, these mobile devices and services might allow them to have instant communication with their relatives who are thousands of miles away and across national borders. According to the International Federation of Red Cross and Red Crescent Societies, giving access to information and technology to migrants should be of equal importance for humanitarian assistance as providing food, water, and shelter (Barros, 2017).

The Central American - U.S corridor is the largest and most concentrated migratory area in the world (Massey et al. 2003). Between 10 and 12 percent of the Central American population has left their birth countries to migrate towards the U.S (Sandoval, 2017). There are numerous reasons why so many people decide to relocate and travel this distance of more than 3,000 miles mostly by walking. Some of the factors that

Suggested Citation (APA): Ferris-Doubles, M. (2019, October 2-5). Central American Migration: Trusting the Mobile Phone To Cross Borders. Paper presented at AolR 2019: The $20^{\text {th }}$ Annual Conference of the Association of Internet Researchers. Brisbane, Australia: AolR. Retrieved from http://spir.aoir.org. 
cause forced migration in the region are institutional and gang violence, territorial dispossession, and unemployment (Batalova, 2017). One must consider the fact that this is the region with the highest rates of murder and gang violence per capita in the world, as well as the Latin American region with more social inequality and corruption (Sandoval, 2017). This situation of severe social exclusion has provoked a massive exodus of Central American people towards the U.S for decades. While they are crossing through the Mexican territory, Central American migrants face hazardous situations of extortion, torture, and kidnapping, as well as abuse and violence from the organized crime and the Mexican migration authorities (Feldmann et al. 2018). This context puts the migrants in a situation of extreme vulnerability and danger, which makes the mobile phone the most accessible and dependable device to achieve a sense of security. Central American migrants are trusting and relying on these technologies for making decisions, creating networks, sharing information, and for connecting with other people (Ros, 2010) These communication technologies are not only changing traditional patterns of migration, they are also enabling and inducing migration by providing feelings of trust, closeness, and safety (Barros, 2017).

There is a growing body of academic work that analyses the uses of mobile phones, social media, and communication applications during the processes of migration (Alonso \& Oiarzabal, 2010; Ross, 2010; Brinkerhoff, 2010). There is a lack of research in regards to which are the central infrastructural and economic arrangements that have taken place that allows Central American migrants to have Internet access and to use the same mobile phone and plan across national borders. By applying methods of historical qualitative research and using a media archeological approach, I employ Durham Peters (2009) theory of infrastructuralism to investigate which are the major infrastructural transitions that have allowed contemporary migrants to use the same mobile phone and plan and to have Internet coverage across multiple national borders during their journey? How have these shifts enabled, induced, changed, and determined new ways and patterns of migration?

I apply elements from the theoretical frameworks of Sociology of Economic Migration and Sociology of Globalization (Sassen,1998) to argue that the implementation of free trade agreements between Central America and the U.S in the 2000s did not only provoke the reorganization of labor in the region, but they also transformed the telecommunication infrastructures from being public utilities into profitable commodities run by private transnational corporations. I argue that the privatization of telecommunications imposed by the Central American Free Trade Agreement with the U.S (CAFTA), has allowed multinational telecommunication corporations to operate and implement their infrastructure across national borders; which allows them to offer "borderless" mobile phone plans which embed and enables emotions of trust, safety, and closeness that have crucial impacts in the ways migration takes place nowadays.

I conclude that these infrastructural shifts have not only allowed mobile phones to change the traditional migratory patterns, but they are also creating a profitable business for a few private transnational telecommunications corporations. My conclusion presents a central paradox which is, that at the same time that the global capital promotes and enables a "borderless" world through the use of communication technologies which in turn promote emotions of trust, safety, and closeness, the nation- 
state borders are becoming more harsh, surveilled, and rigid for the migrants who are constantly harassed, detained, and persecuted.

\section{References}

Alonso, A. and Oiarzabal, P. J. (2010). Diasporas in the New Media Age: Identity, Politics, and Community. University of Nevada Press.

Barros, G. (2017) Central Americans refugees: protected or put at risk by communication technologies? Forced Migration Review, October 2017, University of Oxford, Refugee Studies Centre.

Batalova (April 2, 2017). Migration Policy Institute. www.migrationpolicy.org

Brinkerhoff, A. (2010). Migration, Information Technology, and International Policy. In Alonso, A., \& Oiarzabal, P. J. (Eds) Diasporas in the New Media Age: Identity, Politics, and Community. (pp.19-38) University of Nevada Press.

Feldmann, Andreas E. Xóchitl Bada and Stephanie Schuetze. 2018. New Migration Patterns in the Americas: Challenges for the $21^{\text {st }}$ Century. New York: Palgrave, 1-24.

Fiddian-Qasmiye, Elena, Gil Loescher, Kay Long, and Nando Sigona. 2014. Introduction. In The Oxford Handbook of Forced Migration, Fiddian-Qasmiye, Elena, Gil Loescher, Kay Long, and Nando Sigona eds. Oxford: Oxford University, 1-19.

Massey et al. (2003) in New Migration Patterns in the Americas: Challenges for the 21st Century. New York: Palgrave (2018)

Mezzadra, S and Neilson, B (2013) Border as a Method. Duke University Press. U.S

Peters, John Durham. "Infrastructuralism: Media as Traffic between Nature and Culture." Traffic: Media as Infrastructures and Cultural Practices (2015): 29-49.

Ros, A. (2010). Interconnected Immigrants in the Information Society. In Alonso, A., \& Oiarzabal, P. J. (Eds) Diasporas in the New Media Age: Identity, Politics, and Community. (pp.19-38) University of Nevada Press.

Sandoval, C (2017). Exclusion and Forced Migration in Central America: No More Walls. San Jose, Costa Rica: Springer.

Sassen, Saskia. "The De Facto Transnationalizing of Immigration Policy" In Globalization and Its Discontents. Essays on the New Mobility of People and Money. New York: The New Press. 1998. Pp.5-30

Siles, I (2018): The Internet as a transnational project: connecting Central America through computer networks (1990-1996), Internet Histories 
Walsh (2018) New Migration Patterns in the Americas: Challenges for the $21^{\text {st }}$ Century. New York: Palgrave

Weiner (1993) "Stability, Security, and Migration." International Security 17 (3): 91-126. 